\title{
A Design-Based introduction to learning centres
}

\section{Anne Kristine Petersen}

Associate professor

Centre for Teaching \& Learning, University College Zealand

\section{Astrid Hestbech}

Associate professor

Centre for Pedagogy, University College Zealand

\section{Peter Gundersen}

\section{Associate professor}

Centre for Teaching \& Learning, University College Zealand
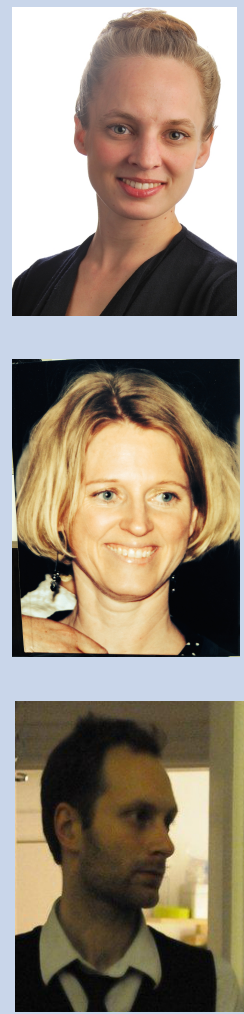


\section{Abstrakt}

Kommuner placeret i yderområder i Danmark har i de seneste årtier oplevet affolkning og økonomisk nedgang, og denne udvikling har medvirket til et centraliseret uddannelsessystem, hvor videregående uddannelsesinstitutioner flyttes fra yderområder til større byer.

University College Sjælland har igangsat et forskningsprojekt i samarbejde med tre kommuner i Region Sjælland og partnere fra de nordiske lande, som har til formål at undersøge hvorvidt uddannelseskonceptet kommunale læringscentre kan medvirke til at løse uddannelsesudfordringer i landets yderområder. Et kommunalt læringscenter er en fysisk lokation som ejes af en kommune, som gennem læringscenteret kan give borgere mulighed for at tage et kursus eller en uddannelse via synkrone og asynkrone koblinger til en uddannnelsesinstitution.

Artiklen præsenterer forskningsresultater, som viser at udviklingen af et økosystem, som fordrer samarbejde mellem kommuner, videregående uddannelsesinstitutioner og private såvel som offentlige virksomheder, er en forudsætning for at opnå en bæredygtig model for online uddannelse i yderområder. Artiklen præsenterer desuden en række tænketeknologier i form af modeller og kategorier, som kan anvendes i arbejdet med at etablere læringscentre og udvikle læringsdesign til konceptet.

\section{Abstract}

In the last decades, outskirt areas in Denmark have suffered from depopulation and economic decline, a development that has led to a centralised education system where higher education institutions are vested in a central body in urban areas rather than in rural communities.

University College Zealand has initiated a research project in collaboration with three municipalities in the region of Zealand and partners from the Nordic countries, which investigates the potential of municipal learning centres as a means to solve educational challenges in outskirt areas. A municipal learning centre is a physical location owned by a municipality, which offers (a)synchronous courses through digital couplings to higher education institutions.

The paper presents research findings showing that the development of an ecosystem based on collaboration between municipalities, higher education institutions and private and public businesses is pivotal for achieving a sustainable model for online education in rural areas. Furthermore, the paper presents a series of thinking technologies in the form of models and categories, which can be used as tools for establishing learning centres and designing learning activities for learning centres.

\section{Centralisation of education and the consequences that follow}

In recent years, citizens in Denmark and other European countries have witnessed how the education sector has become increasingly centralised. The snowball effect of this is 
of no benefit to rural areas and the people living there; citizens are either forced to commute long hours or leave their hometowns in order to study, and many of those who do so, never return. As a consequence, public and private businesses have difficulties recruiting qualified employees for vacant positions, which affects opportunities for development and growth.

One way of effectively fighting against these tendencies, is by providing easier access to education. This can be done, for instance, through online courses such as MOOCs (Massive Open Online Courses), which allow students to study from the convenience of their own homes. However, studies show that although the interest in MOOCs is intense, the typical completion rate is less than $10 \%$ of the total number of students enrolled (Jordan 2014; Pappano 2012; Yuan \& Powell 2013). In line with Downes (cited in Buck 2013, para. 6), we acknowledge that different people have different objectives for entering a MOOC, and recognise that the percentage of people who complete a course is not the only success criterion. Some of the negative attributes of MOOCs, however, may be explained by the lack of the supporting structures and the social environment that we associate with traditional education formats such as academic guidance, study group activities, social activities and technical support.

To meet the challenges of online education, University College Zealand and three municipalities in the region of Zealand, Denmark, have initiated a project that aims at developing a new education format called the municipal learning centre. A learning centre challenges conventional education formats in that it is owned by the local municipality, who decides which courses are offered through digital couplings by one or more education institutions. In this way, the municipality becomes an important strategic player within its region, as the learning centre can help to increase education opportunities for citizens, minimise depopulation and, at the same time, make it easier for local public and private businesses to recruit qualified employees. In a broader perspective, a municipal learning centre may thus help nurture economic growth and development in rural areas.

The paper is divided into four main sections. First, we look into the concept of learning centres and discuss its underlying design principles. Second, we discuss the concept of learning design in relation to learning centres by focusing on two different levels of granularity, namely learning centres as an education format and as a place where designs for learning unfold. Finally, the different levels of granularity are discussed in further detail in two separate sections, which each presents thinking technologies for designing learning centres as a format and as a space where learning designs can unfold.

\section{Methods}

The paper is based on a one-year research and development project, which looked into the potentials and challenges of establishing learning centres in Denmark. The data collected in the project include interviews with municipal staff and local citizens in three municipalities in the Region of Zealand, Denmark, and interviews with staff and 
students at learning centres in other Nordic countries, particularly Sweden which has experience in establishing learning centres throughout the country. In addition to this, the paper draws on observations carried out at a number of different learning centres in the Nordic countries.

Inspired by the growing field of Design-Based Research, the project has aimed at developing new educational theory through iterative testing of prototypes developed in close collaboration with the users (Reeves, Herrington, \& Oliver 2005). Numerous design workshops have been to sketch out a diverse pool of possible learning centre designs rooted in the local premises of each of the participating municipalities. The project findings discussed here are presented in the form of generalised theory related to the education format and the learning design of learning centres, and our findings are thus applicable to other similar contexts.

\section{A Definition of Learning Centres}

On the basis the data described above, the project has defined four design principles, which illustrate what characterises a learning centre:

a) A learning centre is a physical location, where citizens can meet other citizens who also wish to study. A learning centre does not comprise an online platform or an online education portal only.

b) A learning centre connects to education institutions through digital couplings. These couplings may take different forms, including synchronous telepresence or asynchronous learning platforms. The central premise is that the couplings connect the learning centre to one or more education institutions.

c) Teaching at a learning centre takes place through the digital couplings described above. That is, the teachers are not physically present at the learning centre, but various resource staff members may work there, such as mentors, career counselors and technical assistants.

d) A learning centre is rooted in the local community and owned by the municipality. This means that the municipality is in charge of running the learning centre, whereas the education institutions are responsible for offering courses by connecting digitally to the learning centre. The municipality defines the objectives and the design of the learning centre as well as the facilities available.

The four design principles should be seen as a set of general guidelines that allows for a flexible categorisation of learning centres and individually tailored design solutions in which a municipality can decide on the target group, the way in which the digital couplings are carried out and the number as well as the profile of the resource staff members working there. 


\section{The format and learning design of learning centres}

In the following section we discuss learning centres in relation to learning design. Following the four design principles listed above, a learning centre can be seen as both an education format and as a space where learning designs can unfold. This further adds to the complexity of an unsolved challenge within the field of education: The way in which we maintain and share ideas of how to design structures around human learning (Conole 2013; Dalziel 2015; Mor, Craft \& Maina 2015).

A core activity of professional teaching practice is the conceptual preparation of educational interventions in terms of activities, sequences, lessons, units, modules, courses or even whole programmes. Renewed attention has been drawn to the activity of preparation and planning, which is largely due to innovation brought about by the increasing use of digital technologies throughout the educational sphere. In Europe the most commonly adopted name for this field of research, which is concerned with developing shareable models for teaching, is Learning Design (Pozzi, Persico \& Earp 2015). Mor and Craft (2012, p. 86) define learning design as:

\section{'(...) the creative and deliberate act of devising new practices, plans of activity, resources and tools aimed at achieving particular educational aims in a given context'.}

(More \& Craft 2012, p. 86)

The emerging interest in the field is explained by a shift in attention from transmitting knowledge to a passive recipient to structuring the engagement of the targeted learner with the insights enabling them to construct knowledge on their own (Laurillard 2008, p. 527). Laurillard provides an elaborate discussion on learning by drawing on psychology, cognitive science and neuroscience, and concludes that learning can take place in a number of different ways including acquisition, inquiry, practice, production, discussion, collaboration and with the aid of different conventional and digital technologies (Laurillard 2012). Unfolding the richness of the framework presented by Laurillard is beyond the scope of this paper, but it should be mentioned that designing for learning involves more than simply knowing how knowledge can be transmitted; designing for learning involves a complex and iterative process in which the teacher herself becomes a learner through progressive refinement.

A useful metaphor for understanding the aim of learning design is that of music notation. In the past, it has been argued that music notation is impossible, because music is too 'ethereal' (Dalziel 2015). However, today there are several different ways of translating music into scores that allow for a unique piece of music to travel from one hand to another. It could be argued that an important difference between a typical musical performance and a classroom experience is that music is usually reproduced 'as is', whereas many educators would adapt and change any shared idea to best suit their learners. However, in certain musical genres, jazz for instance, improvisation and 
adaptation is a part of the musical experience, even though the outcome can still be notated (Dalziel 2015).

The difference between the notation and the performance of a piece of music can be compared to the difference between a learning design (a plan for potential activities) and the implementation of it, also referred to as a running learning design or a running sequence (Dalziel 2015). This distinction is important because a descriptive framework need not describe everything in relation to the educational experience. Rather, it should aim at providing sufficient information to allow one educator to replicate effectively the teaching and learning ideas of another educator. As pointed out in the Larnaca Declaration, which was written at conference in Larnaca in 2012, teaching does not take place in a vacuum (Dalziel, Conole, Wills, Walker, Bennett, Dobozy \& Bower 2013). Represented through the Learning Design Conceptual Map in Figure 1, the teaching cycle is influenced by important factors such as educational philosophy and methodologies, the characteristics and values of educators and learners as well as institutions and the level of granularity of the design.

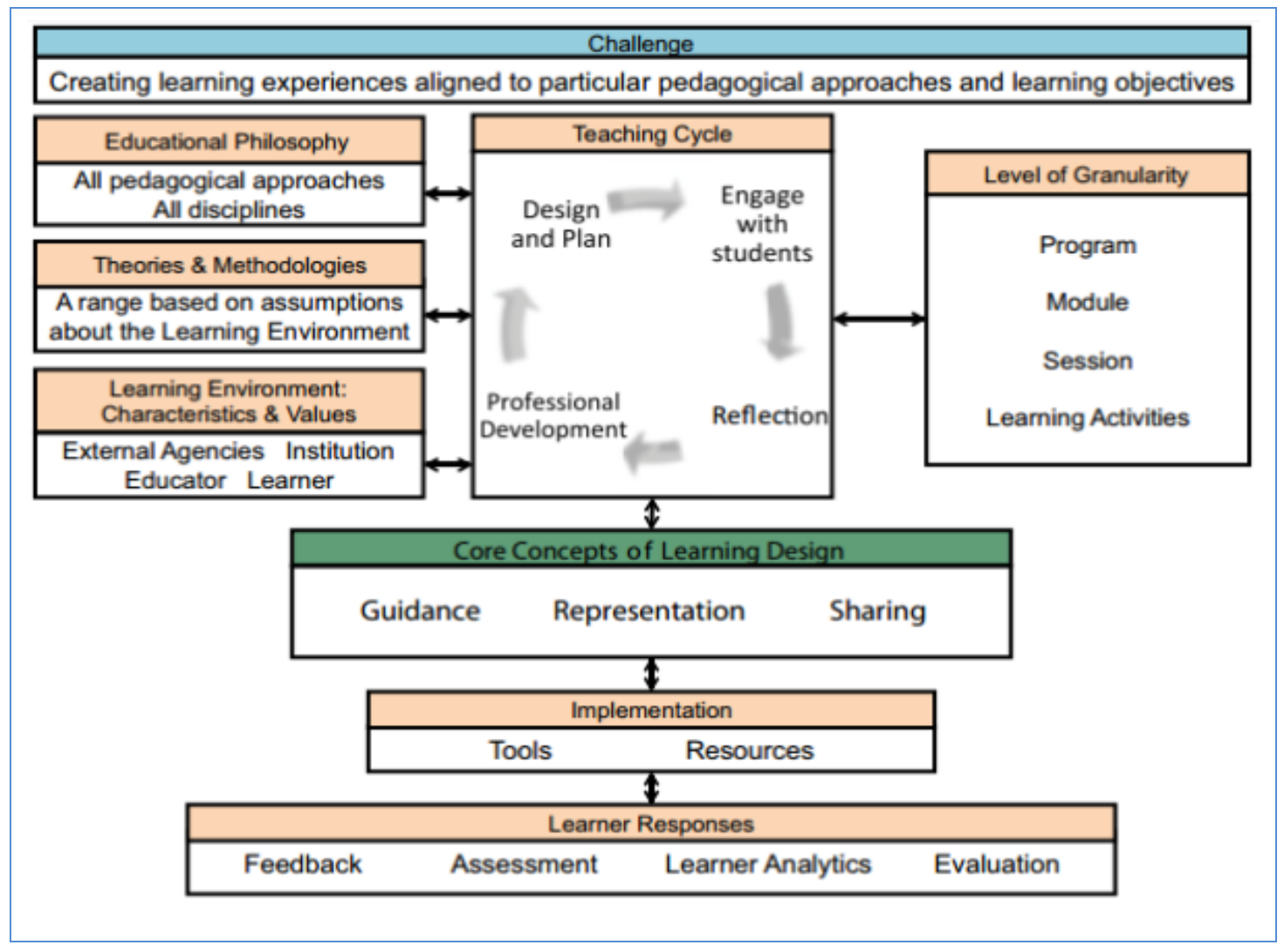

Figure 1: The Learning Design Conceptual Map. From Dalziel, Conole, Wills, Walker, Bennett, Dobozy \& Bower 2013, p. 14.

In this paper, we will focus particularly on the level of granularity as illustrated in Figure 1. Staying within the musical metaphor, we find it just as important to analyse the format through which the music (and learning) is transmitted as how to describe it. 
There is indeed a difference in being exposed to music through the spontaneity of street music, going to a concert, buying a record or streaming music online. With the evolution of technology, the ways in which education can be offered are equally diverse.

In an educational context, various payoffs have been promised with each new wave of technological advancement. From hardware, such as tablets, where access to unlimited content has promised students to hold all of the world's information in their hands, to the case of MOOCs, where teachers are able to educate a huge number of students across the globe at a low cost and with seemingly unlimited scalability (Kolko 2014). Distance learning promises a payoff in terms of convenience by rendering it possible for students in remote areas or students with non-academic obligations (e.g. families) to study at home. It seems, however, that when it comes to technological advancements in education, there is a tendency to focus one-sidedly on efficiency-related payoffs at the expense of the user's learning experience.

As Kolko (2014) points out, design is often seen as a forgivable attribute in that users tend to forgive clunky or downright unappealing forms of design as long as the promised payoff is great enough. However, when it comes to designing new education formats, the learning experience itself, rather than the benefits of ease and economy, should be at the center of attention.

As we will see in the following, learning centres have many benefits of ease and economy for rural areas and the people living there; citizens may avoid commuting long hours to study, and it becomes easier for public and private businesses to recruit qualified employees. In our view, however, the format of a learning centre should not compromise a good learning experience because in education, this is always an essential and valuable payoff for the learner.

In the following two sections we present a number of thinking technologies (Staunæss \& Bjerg 2013) for education and learning designers in the form of models and categories, which can be used as tools for establishing learning centres and designing learning activities for learning centres. In the first section, the thinking technologies presented thus focus on learning centres as education formats rooted in a local community and in the second section a framework for lecturers designing online (a)synchronous teaching at learning centres is presented.

\section{The education format of learning centres}

A Swedish system of ideas referred to as the $3 M$ functions (motor, mediator and meeting place) will be introduced in the following to elucidate how different types of learning centres can create educational and economic value in rural areas. The $3 \mathrm{M}$ functions have shown useful as a general design framework for learning centres in Sweden. The terms were originally mapped out in 2001 (Grepperud \& Thomsen 2001) and as Swedish experiences show, they can be used for designing, developing and ensuring the quality of learning centres. The $3 \mathrm{M}$ functions are presented here for two 
reasons: Firstly, it is assumed that the three functions are equally useful as a general design framework in a Danish context, which is in many ways comparable to that of our neighbouring country. Secondly, the $3 \mathrm{M}$ functions serve to illustrate an important point, namely that a learning centre should be designed to strategically meet the local educational needs of the municipality in which it is located.

\section{The Motor}

The strategic reasons for establishing learning centres in Sweden are found in their potential contribution to regional growth and development in municipalities that suffer from depopulation, decrease in the level of education and job cuts in the private and public sectors. Thus, the underlying vision of the concept is that the learning centre may serve as an organisational motor that drives local development. This means that learning centres must collaborate with a range of partners including education institutions (e.g. universities or university colleges), libraries, employment services, unemployment funds and other players in order to establish common visions, goals and strategies for the establishment of an infrastructure, which can support adult skills development in the municipality.

It should be noted that the motor of a learning centre can have at least three different functions. Firstly, the educational activities taking place in the learning centre may create a local awareness in the students' circles of acquaintances that can motivate other citizens to start studying themselves. Secondly, the learning centre may serve as a motor for growth within the business sector as an increase in the level of education will make it easier for local businesses to recruit qualified employees and, moreover, learning centres may offer skills development courses tailored specifically to match the competency needs of local businesses. Thirdly, the motor may have a politically strategic function as an arena of development, where politicians and businesses collaborate in creating visions and setting goals for the municipality in order to generate economic growth and minimise the emigration rate.

\section{The mediator}

The mediator function is what renders learning centres unique from a Danish perspective, and it is also what makes the Swedish approach interesting in terms of regional development. The mediator function serves the purpose of mediating between competencies required in the municipality on the one hand, and educational needs on the other. This mediation can, however, be carried out in many different ways, and it is essential to distinguish between a passive mediator and an active mediator (Hattinger, Hellsten \& Snis 2007). A learning centre based on a passive mediator function simply provides e.g. information on courses and may in this sense resemble a library, whereas learning centres that actively mediate will, for instance, map out the needs for skilled labour in the municipality and its surrounding areas in collaboration with the regional competency council, adult education institutions such as universities as well as public and private businesses in the area. This mapping of the local needs for skilled labour thus dictates which courses are offered by the learning centre as well as the number of 
student places allocated for each course. In this way, there is a high probability that students will indeed succeed in getting a job in the area in which they live once they graduate. It should be stressed that although learning centres assuming the role of an active mediator may seem to be doing the job of employment services, the function of the learning centres is radically different; the employment service seeks to match a vacant position with a qualified job seeker, whereas the learning centre seeks to match a potential future job opportunity with educational opportunities in terms of courses that will eventually result in graduates qualified for the future jobs identified within the municipality. Consequently, education becomes a means to regional growth.

\section{The meeting place}

The meeting place function covers both the organisational and the pedagogical aspects of a learning centre (Hattinger, Hellsten \& Snis 2007), as well as the physical and virtual places in which students, teachers, mentors and other resource staff members meet. While a learning centre is similar to other (a)synchronously coupled education formats, the meeting place of the Swedish learning centres is unique compared to a Danish context in at least one respect: In Sweden, learning centres are owned by the municipality in which they are located, and the municipalities rather than the education institutions decide which courses to offer.

While the 3M functions described above illustrate the functions of the Swedish learning centres and are useful as thinking technologies for designing the format of a learning centre, the functions do not give us any guidelines as to the kind of learning designs that can be applied to the concept. For this reason, we argue that the design framework of learning centres should include not only the $3 \mathrm{M}$ functions, but also consider the functions of learning design.

Before we move on to discuss the actual learning design of learning centres, we will sum up the previous sections by visualising the $3 \mathrm{M}$ functions of learning centres as illustrated in Figure 2. 


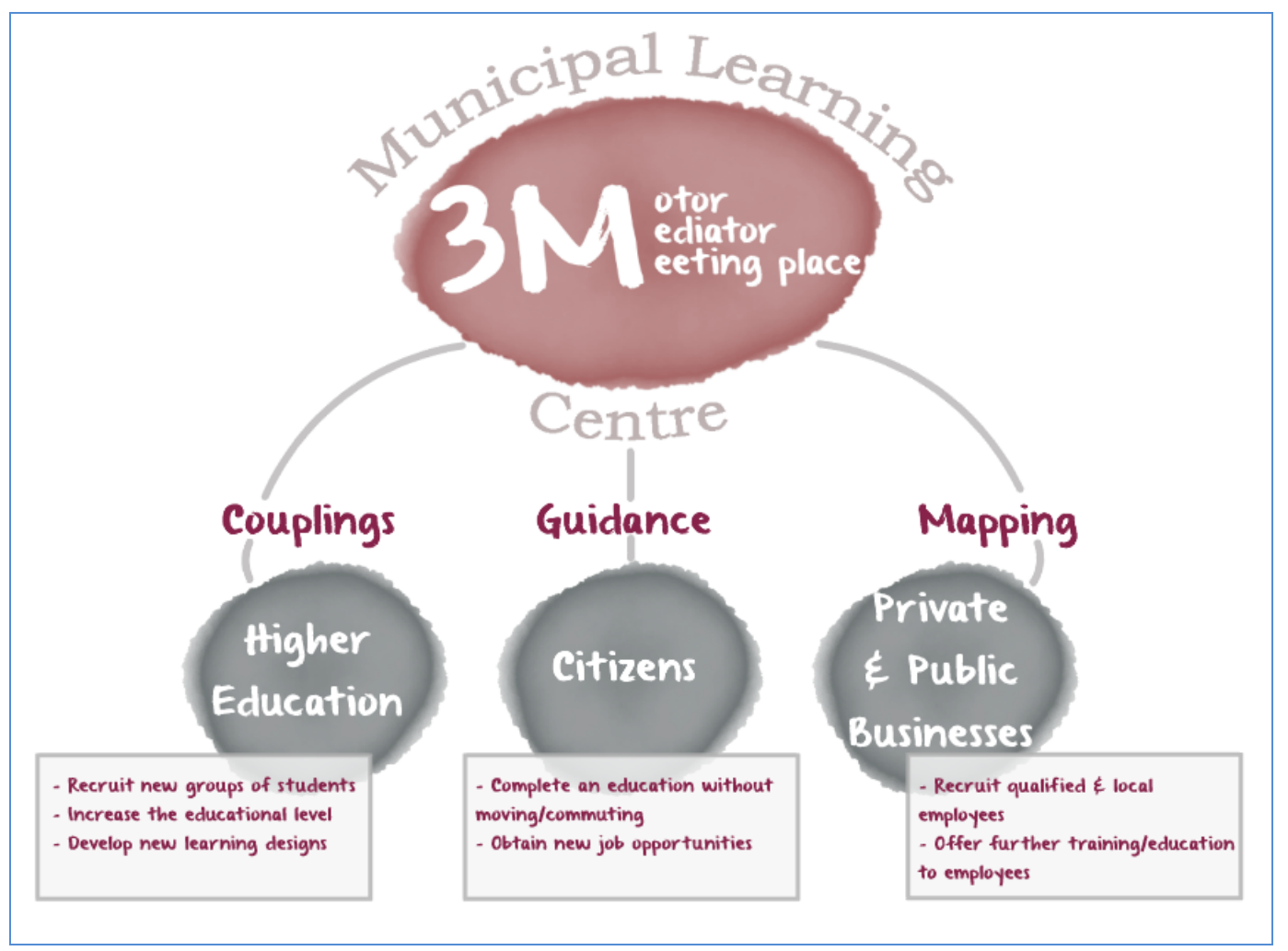

Figure 2: The 3M functions (motor, mediator and meeting place) of the municipal learning centre.

As already mentioned, learning centres are unique in the way they interact with agents in the local community and, as shown in Figure 2, an extensive mapping needs to take place in order to identify and match the competency needs of the public and private businesses with relevant courses that will give citizens the opportunity to become qualified for future jobs.

Furthermore, the learning centre seeks to guide local citizens to choose an education and consequently a future job that is suitable for them, which gives those who wish to remain in the area a relatively safe career path. Finally, the learning centre must create digital couplings to higher education institutions in order to be able to offer the teaching expertise needed. An obvious reason for universities and university colleges to get involved in this is the chance of increasing student intake. However, we argue that it is just as important for education institutions and educators to develop new and more effective learning designs with the use of new technology when engaged in designing new education formats.

\section{New settings and roles for students}

To be a student at a learning centre requires other prerequisites and approaches than is required in a traditional classroom setting. Although students at a learning centre do interact with lecturers as well as other students, they often do so digitally, which means that like other e-learning students, they become coordinators for their own studies (Prak 2007; Willging 2015). The advantage of studying at a learning centre is the fact 
that students can take example from fellow students in the classroom, which makes it easier for students to structure and form an overview of their education as well as to maintain and develop self-motivation. In this context, self-motivation is seen as occurring when students are in control of their own learning processes and evaluate themselves, whereas extrinsic motivation refers to motivation that is driven by external factors, such as other people, passing exams, etc. (Sørensen 2013). It is often argued that the relatively high drop-out rates associated with online education are partly caused by the fact that students must coordinate their own studies and motivate themselves. However, empirical data collected from a learning centre in Sweden show a drop-out rate of only $5 \%$, which indicates that students are more likely to complete their online studies if they physically meet with their peers on a regular basis.

As mentioned previously, learning centres are based on the premise that higher education institutions are responsible for conducting teaching, and it is the job of the learning centre to support this by making sure that e.g. mentors, supervisors and technical assistants are at the students' disposal. A learning centre is, in other words, not an education institution; it is a physical and virtual meeting place. However, students and lecturers at learning centres still face new challenges. The channels of communication, for instance, differ radically from a conventional classroom setting, and it is thus important to support social telepresence to strengthen the students' feelings of mental and social presence in a place from which they are physically displaced. Consequently, it is essential to develop learning designs that enhance students' feelings of active participation and the lecturer must be able to successfully facilitate through one or more screens. Surveys exploring factors that influence e-learning show that the lecturer's attitude on e-learning has a significant impact on the nature of his or her teaching (McNaughton, Westberry, Billot, \& Gaeta 2014), and it should be stressed that

'(...)technological artifacts are not neutral intermediaries but actively coshape people's being in the world: Their perceptions and actions, experience and existence'.

(Verbeek 2011, p. 8)

In order to meet the challenges related to online learning environments, a number of learning centres in Sweden have introduced the concept of mentors. Mentors attend lessons and other study activities, but they are not lecturers, that is, they do not conduct teaching or hold examinations. Mentors are particularly useful when studies are dialogue-based and require the presence of a facilitator, because the mentors can physically assist the digitally coupled lecturer by supporting and facilitating students' dialogue at the learning centre.

\section{Learning designs for learning centres}

In order to offer courses to students, a learning centre must digitally connect to one or more education institutions through the use of e.g. videoconferencing. In line with Luhmann (Luhmann 2000; Rasmussen 2007), we define digital couplings as a relation 
of dependency that is established between different contexts which either share the same purpose/logic (e.g. in relation to teaching and learning) or have different purposes/logic (which is, for instance, the case for businesses and education institutions) (Christiansen et al. 2014).

In a learning centre, couplings can take place between a number of different partners. Figure 3 illustrates how a lecturer who is physically present at an education institution is digitally coupled to two different groups of students at two different learning centres through synchronous or asynchronous communication channels:

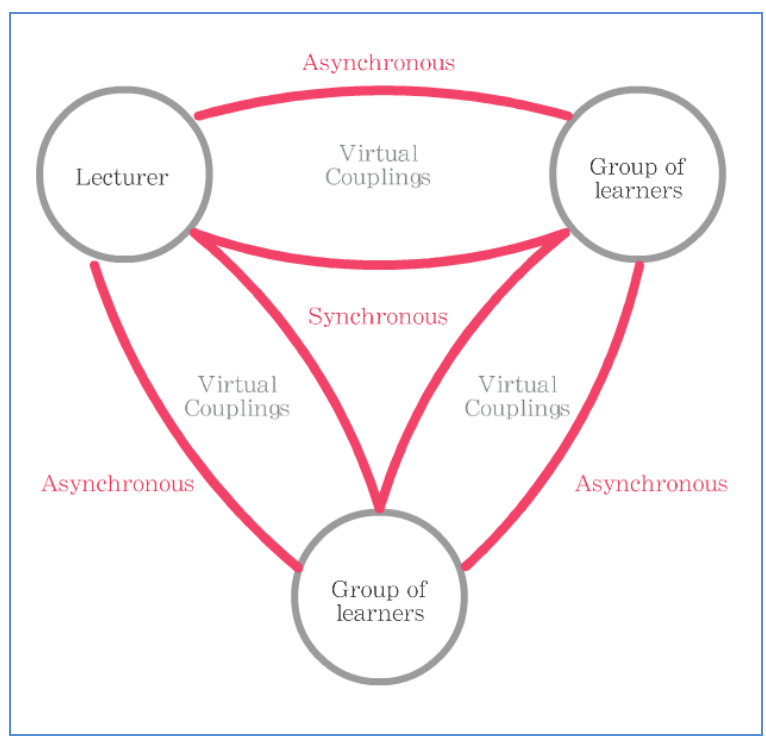

Figure 3: Illustration of a learning centre in which two different groups of students at two different learning centres are digitally coupled to a lecturer through synchronous or asynchronous communication channels.

It should be noted that groups of students can be digitally coupled in many different ways and that new channels of communication require practice in terms of technical as well as communicative skills. The digital couplings can, as illustrated above, be synchronous or asynchronous, and the two types of couplings lead to different possibilities in terms of learning designs. The terms synchronous and asynchronous derive from the research field of Computer--Supported Cooperative Work (CSCW), where they are used to describe whether couplings occur simultaneously as in videoconferencing or are temporally displaced as is the case for the message board of a Learning Management System (LMS). The two terms, synchronous and asynchronous, are often used with the terms situated and distant, which indicate whether activities take place in the same location or in different locations. This is, however, less important in relation to learning centres because they always couple at least two different locations, namely an education institution and one or more learning centres.

The design of a learning centre depends on the types of educational activities that students will digitally engage in. This means that the chosen types of support and technology are inseparably bound up with the group of students that a given learning 
centre seeks to target through its design. These design choices thus require careful consideration in order to create a successful learning environment.

Moreover, synchronous and asynchronous communication channels result in different affordances and restraints (Christiansen \& Gynther 2013). Affordance relates to the potential behaviour encouraged by a given technology, whereas the term restraint describes the behavioural limitations set by a given technology. The differences between synchronous and asynchronous digital couplings can be shortly summarised as follows:

\begin{tabular}{|l|l|l|}
\hline & Synchronous digital couplings & Asynchronous digital couplings \\
\hline Contents & Facilitated in real time & Materials are editable \\
\hline Form & $\begin{array}{l}\text { The form is changeable } \\
\text { throughout the course, and } \\
\text { progression is controlled by the } \\
\text { lecturer }\end{array}$ & $\begin{array}{l}\text { The form is relatively fixed, and } \\
\text { progression is controlled by the } \\
\text { student }\end{array}$ \\
\hline Interaction & $\begin{array}{l}\text { Interaction happens } \\
\text { instantaneously }\end{array}$ & Interaction is temporally displaced \\
\hline Time & Teaching is set in real-time & Teaching is temporally flexible \\
\hline
\end{tabular}

Figure 4: An overview of the differences between synchronous and asynchronous digital couplings.

Contents: The academic contents of synchronous and asynchronous teaching are defined by a curriculum and an educational executive order. In asynchronous teaching, the lecturer can edit how the contents are facilitated. For instance, videos can be edited and there is time to carefully consider the contents of assignments and presentations. In synchronous teaching, the contents are facilitated in real-time and any changes or additions must be made on the spot by the lecturer.

Form: In asynchronous teaching the student is in charge of the course and hence the pace of his or her learning process; the student can concentrate upon difficult topics and can watch videos again if necessary. If synchronous lessons are recorded, students can also rewatch parts of the lessons, but they cannot control the pace in order to focus on specific topics during the actual lessons. In asynchronous teaching, the lecturer decides how lessons are conducted, whereas in synchronous lessons, students can influence the way teaching is carried out by interacting with the lecturer and by discussing the teaching forms, whereas this is rarely possible in an asynchronous setting.

Interaction: In synchronous teaching, prompt interaction can take place in that both students and the lecturer receive immediate feedback on their contributions. This kind of interaction resembles the kind of interaction that students are familiar with from a 
traditional classroom setting and special prerequisites are not required from the students. In asynchronous teaching, communication is maintained and it is thus possible to watch or listen to resources several times and bury oneself in specific topics. The advantage of asynchronous teaching is the fact that it allows for reflection on and discussion of complex topics.

Time: Synchronous teaching takes place at a specific time and place, which may be a disadvantage if students have other obligations such as a job and a family. Asynchronous teaching, on the other hand, is easier to fit into students' individual schedules as it can usually take place anywhere and anytime.

According to the empirical data collected, the users of learning centres ask primarily for synchronously coupled technologies such as teaching through telepresence and guidance through online meetings. Fast and reliable feedback is also considered important. One of the major advantages of synchronous interaction is the fact that feedback can be given instantly, and empirical data confirm that students consider instant feedback particularly crucial in online learning environments.

To experience interaction with a lecturer (that is, to experience presence) and to be aware of what other students are preoccupied with (that is, to exercise awareness) is important in feeling included. Furthermore, students are less likely to experience feelings of isolation in synchronous online learning environments as opposed to asynchronous learning environments (McBrien, Cheng \& Jones 2009), and they feel more motivated to complete their studies if courses involve close and frequent interaction with other people.

It should be mentioned that different parts of courses and topics within a subject may be more or less suitable for synchronous or asynchronous activities. For this reason, it is essential for lecturers and students to discuss what kind of digital couplings and technologies are appropriate in relation to specific parts of a course, topics within a course and the requirements that students are to meet (Christiansen et al., 2014).

Education institutions tend to offer courses through either synchronous or asynchronous digital couplings, but this simplistic approach does not allow us to achieve the full potentials of the technologies available today. We argue that all teaching situations should be planned carefully to ensure that the most suitable learning design, which takes into consideration successful facilitation of the academic contents as well as the students' prerequisites, is chosen. In this way, students are offered flexible learning conditions and the affordances and restraints of a given technology can be taken into account, which means that the learning approaches and working methods of each student may be considered within the learning design.

\section{Conclusion}

A municipal learning centre is a radical educational innovation that has the potential to solve some of the socio-pedagogical issues we are currently facing in developed 
countries. As a design solution, it is based on the premise of equal rights for all citizens to access education regardless of where they live. At the same time, learning centres are a means for rural areas to play an active role in countering the current trends of centralised education and depopulation. Learning centres have been successfully implemented in Sweden, but the concept nevertheless has unexplored potentials in terms of developing effective learning designs that, given the right circumstances, can help foster regional growth in areas at the risk of economic decline.

The thinking technologies discussed in this paper can help nurture the continuous development of new education formats and effective learning designs. In relation to the latter, it is crucial to consider how and when to employ synchronous and asynchronous digital couplings by taking into consideration aspects such as contents, form, interaction and time. Similarly, the three metaphorical functions of motor, mediator and meeting place are useful as strategic thinking technologies for establishing, sustaining and developing learning centres in rural areas. On a concrete level, this can be done by effectively mapping business needs, guiding citizens to future jobs and by offering courses via synchronous and asynchronous digital couplings between the physical meeting place of the learning centre and education institutions.

Acknowledging that many aspects of learning centres still need to be further explored, the aim of this paper is to elucidate an emerging field of research on learning centres as an education format as well as a place where learning designs unfold.

\section{References}

Buck, T. E. (2013). The massive effects of MOOCs in higher education. Retrieved from http://www.edtechmagazine.com/higher/article/2013/01/massive-affectmoocs-higher-education

Christiansen, R. B., \& Gynther, K. (2013). Synkrone læringsmiljøer i erhvervsuddannelserne: Erfaringer, analyser og anbefalinger med baggrund i fire erhvervsskolers afprøvning af fællesundervisning i ernæringsassistentuddannelsen understøttet af videokonferenceteknologier. Rapport. (59 s.) Sorø: UCSJ forlag. Retrieved from

http://fou.emu.dk/offentlig_show_projekt.do?id=197622

Christiansen, R. B., Schlüntz, D. A., Christensen, O., Helms, N. H., \& Gynther, K. (2014). Kan vi lære af de andre?: - udenlandske erfaringer med e-læring og blended learning i erhvervsuddannelser og læreruddannelser for erhvervsskolelærere. Sorø: UCSJ Forlag. Retrieved from http://ucsj.dk/fileadmin/user_upload/FU/Publikationer/Kan_vi_laere_af_de_and re.pdf 
Conole, G. (2013). Designing for learning in an open world. New York, NY: Springer.

Dalziel, J., Conole, G., Wills, S., Walker, S., Bennett, S. Dobozy, Bower, M. (2013). The larnaca declaration on learning design - 2013. Retrieved from www. larnacadeclaration.org

Dalziel, J. (2015). Reflections on the Art and Science of Learning Design and the Larnaca Declaration. The Art \& Science of Learning Design (2015): 3-14.

Grepperud, G. \& Thomsen, T. (2001). Vilkår for et regionalt utdanningsløft Vurdering av Studiesenteret på Finnsnes 1996-2001. Slutrapport. U-VETT, Universitetet i Tromsø. Høgskolen i Harstad.

Hattinger, M., Hellsten, J-O. \& Snis, U. L. (2007). Lärcentrum - perspektiv och Möjligheter - Analys och praktik. Nationalt centrum för flexibelt lärende. Rapport $1: 2007$.

Jordan, K. (2014). Initial trends in enrolment and completion of massive open online courses. The International Review of Research in Open and Distance Learning, 15(1), 133-160. Retrieved from http://www.irrodl.org/index.php/irrodl/article/view/1651

Kolko, J. (2014). Why Investment in Design is the Only Way to "Win" in Education, Published in UX Magazine, September, 2014.

Laurillard, D. (2008). Technology enhanced learning as a tool for pedagogical innovation. Journal of Philosophy of Education, 42, 521-533.

Laurillard, Diana. (2012). Teaching as a Design Science: Building Pedagogical Patterns for Learning and Technology. NY: Routledge Taylor and Francis Group.

Luhmann, N. (2000). Sociale systemer- grundrids til en almen teori. Gyldendal Akademisk. 
McBrien, J. L., Cheng, R. \& Jones, P. (2009). Virtual spaces: Employing a synchronous online classroom to facilitate student engagement in online learning. The International Review of Research in Open and Distributed Learning 10.3.

Mor, Y. \& Craft, B. (2012). Learning design: reflections on a snapshot of the current landscape. Research in Learning Technology, vol. 20.

Mor, Y., Craft, B. and Maina, M.(2015). The Art \& Science of Learning Design. Springer.

McNaughton, S., Westberry, N., Billot, J., \& Gaeta, H. (2014). Exploring teachers' perceptions of videoconferencing practice through space, movement and the material and virtual environments. Journal of Mixed Research Approaches, 8, 8799.

Prak J-H. (2007). Factors Related to learner dropout in online learning. Retrieved from http://files.eric.ed.gov/fulltext/ED504556.pdf

Pozzi, F., Persico, D. \& Earp, J. (2015). A Multi-Dimensional Space for Learning Design Representations and Tools. The Art \& Science of Learning Design (2015): 49-62.

Rasmussen, J., Kruse S. \& Holm, C. (2007): Viden om uddannelse. Uddannelsesforskning, pædagogik og pædagogisk praksis. Hans Reitzels Forlag

Reeves, T. C., Herrington, J., \& Oliver, R. (2005). Design research: a socially responsible approach to instructional technology research in higher education. Journal of Computing in Higher Education, 16(2), 96-115.

Staunæs, D. \& Bjerg, H. (2013). Tænketeknologier. Når forandringer består projekter forgår. In: Skolen i morgen, 8, 4-6.

Sørensen, N.U m.fl. (2013). Unges motivation og læring. Hans Reitzels forlag.

Verbeek, P.-P. (2011). Moralizing Technology. The University of Chicago Press Books. 
Yuan, L., \& Powell, S. (2013). MOOCs and open education: Implications for higher education. CETIS White Paper. Retrieved from http://publications.cetis.org.uk/wp-content/uploads/2013/03/MO0Cs-andOpen-Education.pdf 